\section{JC BIBLIO COUNS}

Biblio Couns: Jurnal Kajian Konseling dan Pendidikan

Vol. 2, No. 3, November 2019, hlm. 105-108 Tersedia Online di jurnal.umsu.ac.id/index.php/biblio

ISSN 2620-3103 (online)

DOI: https://doi.org/10.30596/bibliocouns.v2i3.3709

\title{
Motivational Achievement Relationship and Procrastination Academic
}

\author{
Sefni Rama Putri, Ilham Khairi Siregar \\ Universitas Muhammadiyah Sumatera Utara, Indonesia Korespondensi: Jl. Muchtar Basri No. 3 \\ Medan,Indonesia. Email : sefnirama@umsu.ac.id
}

Article Info

History of Article

Submited November 2019

Accepted November 2019

Published November 2019

\section{Key Word}

Motivational Achievement, Procrastination Academic.

\begin{abstract}
Research studies on the low motivation of achievement of students towards the high degree of academic procrastination in the course of lectures. The research aims to get a motivational depiction of student study and counseling studies Program and get an overview of student academic procrastination. This research sample is a tutoring and counseling student amounting to 75 people using a random aiming technique. The instrument used is the motivation scale of achievement and academic procrastination. Furthermore, the prerequisite tests include test normality and linierity testing, as well as simple regression analyses. Based on the analysis results obtained an $R$ value of -0.252 which shows the regression coefficient between achievement motivation and students' procrastination with an R-Square value of -0.063 . This shows that achievement motivation is negatively related to academic procrastination of $6 \%$. In line with the research results that high achievement motivation can decrease students academic procrastination in lecturing.
\end{abstract}

\section{Citation Info}

Putri, S.R. \& Siregar, I.K. (2019). Motivational achievement relationship and procastination academic. Biblio Couns: Jurnal Kajian Konseling dan Pendidikan, 2(03), 105-108. 


\section{INTRODUCTION}

The problem of this research started with student negligence in completing coursework assignments and making learning achievement low. Many of them feel that the lecture process is complicated and troublesome, time-consuming. (Rumini, 2006) Expressed the tendency to delay in carrying out an activity called procrastination. Regarding the academic sphere, procrastination is described as the conduct of postponing academic duties to the deadline of available time. The delay in completion of this academic task is called academic procrastination. The academic procrastination is closely related to the achievement of student motivation.

(McClelland, 1987) Presents an achievement motivation is an attempt to achieve success or success incompetency with a measure of excellence of one's achievement concerning achievement, which is mastering, manipulating and regulating Social and physical environments, overcoming all obstacles, and maintaining high quality of work. Achievement motivation demands individuals to improve their fully-owned skills to achieve the best results.

Achievement motivation is said to be weak is to suspend tasks, consider what he suffered is a result of low ability, difficulty in task, have no desire to compete with his friends, And do not feel embarrassed by the failure in his face, it is expressed as a motivation to achieve a low in students and will be a complex problem that raises procrastination in students. Meanwhile, high achievement motivation in students can be the ability to improve learning performance, the ability to overcome all obstacles in learning, to maintain the quality of learning, competence in achieving higher achievements Again, seeking solutions to tasks in task work, an embarrassment of failure, and attempting to avoid failure with accomplishment. Based on the explanation above, it can be concluded that achievement motivation is influenced by academic procrastination, which can be a complex problem for students especially in the effective implementation of daily life. Several studies have shown that motivation influences learning (Oktasari, 2018; Saragi, Iswari, \& Mudjiran, 2016; Saragi \& Suryani, 2018).

Guidance and counseling play an essential role in helping students to alleviate their problems. This can be done with the implementation of content mastery services to students.

\section{METHOD}

The population in this study is the students who are running the lecture process in the second semester, four, and six in the program of the guidance and counseling for FKIP UMSU. Based on the population, researchers took samples using a one-class purpose random sampling technique representing each generation of a class of two semesters, one class of semester four, and one class of semester six, amounting to 75 people. The variables in this study were the motivation for student achievement and academic procrastination.

The research procedure was conducted by providing achievement motivation instrumentation and academic procrastination instruments of students to research samples, and after that, gathered the results of the replenishment of the instrument for subsequent analysis of data. Test the data descriptions by creating a frequency table and standard deviation, as well as setting the criteria for the respondent's achievement 
assessment. A prerequisite test is test of normality and linearity testing, as well as hypothesis testing using simple regression statistical tests to see the percentage of influence of each variable.

\section{RESULTS AND DISCUSSIONS}

A description of the results of the study is presented in the form of the following diagram:

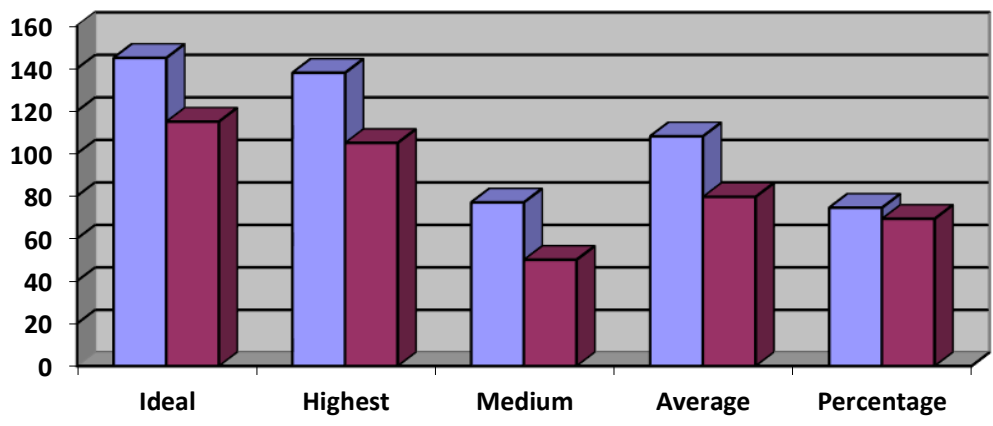

口Achievement Motivation

$\square$ Academic Procrastination

Based on the analysis of the results of the study obtained the highest score on the achievement motivation variable of 138 , with an average percentage of $74.5 \%$ of this variable score is in the high category. Furthermore, based on the analysis of the results of research on the variable academic procrastination obtained the highest score of 105 with an average of $69.3 \%$ the score of this variable is in the high category. However, of the total samples examined as many as 75 people, there were 40 people whose sample scores of procrastination were low at 50, which means $50 \%$ of the sample had low academic procrastination scores. In line with the opinion of (Djaali, 2008) motivational factors for achievement include abilities, needs, interests, and hopes/beliefs. Based on the opinion, 40 samples have confidence, interests, and needs for education, and this is evidenced by the achievement motivation score of 130-138 with a high category. This means that the high achievement motivation of these students who have interests, beliefs, and needs for education makes students get a low academic procrastination score.

\begin{tabular}{ccc}
\hline Model & $\mathbf{R}$ & R Square \\
\hline $\mathbf{1}$ & -0.252 & -0.063 \\
\hline
\end{tabular}

After simple regression analysis, achievement motivation and academic procrastination found the R-value of -0.252 which shows the regression coefficients between achievement motivation and student academic procrastination. Furthermore, the value of $\mathrm{R}$ Square of -0.063 indicates that $6 \%$ achievement motivation is negatively related to student academic procrastination.

Then, a simple regression significant test was performed, which found an $F$ value of 8.518 with a significant level of 0.004 . The probability is smaller than the significant level of 0.05 , which means the correlation coefficient between achievement motivation and student academic procrastination is significant.

\section{CONCLUSIONS}

Based on the results of the study showed that overall guidance and counseling study program students already have high achievement motivation but also have high 
academic procrastination. It is seen that there are still students who do not collect assignments on time and procrastinate to do the assignments given by the lecturer. Achievement motivation leads to individual success in competition with several standards of excellence for success. In individual competition, it may fail to achieve its goals, but with this competition it still allows one to try harder to achieve the desired achievement.

Conditions of high achievement motivation need to be maintained, developed, and improved in lectures. Because after all, students arrive at conditions like this are not secure. Someone who has high achievement motivation is someone who likes to work hard, never give up, and wants to complete tasks promptly by utilizing a short amount of time. Motivation in an individual to achieve success or achievement is one of the factors of academic procrastination.

Based on the results of research and analysis that has been done prove that there is a negative relationship between achievement motivation with academic procrastination of $6 \%$. This shows that the higher the achievement motivation, the lower the student academic procrastination, conversely the lower the achievement motivation, the higher the student academic procrastination.

\section{ACKNOWLEDGMENTS}

This research was carried out based on the results of the beginner lecturer research at the institution where I work. Funding was provided by the agency, and in the course of this research, I was assisted by my colleague.

\section{REFERENCES}

Djaali. (2008). Psikologi Pendidikan. Jakarta: Bumi Aksara.

McClelland, D. C. (1987). Human motivation. Human motivation. New York, NY, US: Cambridge University Press.

Oktasari, M. (2018). Hubungan persepsi siswa tentang dukungan sosial teman sebaya terhadap motivasi berprestasi siswa. Biblio Couns: Jurnal Kajian Konseling Dan Pendidikan, 1(1). https://doi.org/https://doi.org/10.30596/bibliocouns.v1i1.1940

Rumini. (2006). Prokrastinasi Akademik Ditinjau Dari Motivasi Berprestasi Dan Stres Mahasiswa. Jurnal Psikologi Undip, 3(2), 37-48. https://doi.org/10.14710/jpu.3.2.37

Saragi, M. P. D., Iswari, M., \& Mudjiran, M. (2016). Kontribusi Konsep Diri Dan Dukungan Orangtua Terhadap Motivasi Belajar Siswa Dan Implikasinya Dalam Pelayanan Bimbingan Dan Konseling. Konselor, 5(1), 1. https://doi.org/10.24036/02016516477-0-00

Saragi, M. P. D., \& Suryani, R. (2018). Perbedaan motivasi belajar siswa berjenis kelamin perempuan dan laki-laki SMK Swasta Bandung. Jurnal Penelitian Bimbingan Dan Konseling, 3(1), 60-68. Retrieved from http://jurnal.untirta.ac.id/index.php/JPBK/article/view/3197 